\title{
Community compositions of Bacteria and Archaea in the Sea of Okhotsk during summer
}

\author{
Hongmei Jing ${ }^{1}$, Hongbin Liu ${ }^{1, *}$, Koji Suzuki ${ }^{2}$, Rumi Sohrin ${ }^{3}$, Jun Nishioka ${ }^{4}$ \\ ${ }^{1}$ Department of Biology, The Hong Kong University of Science and Technology, Clear Water Bay, Kowloon, \\ Hong Kong SAR, China \\ ${ }^{2}$ Faculty of Environmental Earth Science, Hokkaido University, North 10 West 5, Kita-ku, Sapporo 060-0810, Japan \\ ${ }^{3}$ Institute of Geosciences, Shizuoka University, 836 Oya, Shizuoka 422-8529, Japan \\ ${ }^{4}$ Institute of Low Temperature Science, Hokkaido University, North 19 West 8, Kita-ku, Sapporo 060-0810, Japan
}

\begin{abstract}
We investigated spatial variations of the bacterial and archaeal community composition in surface waters of the Sea of Okhotsk during summer of 2006, using denaturing gradient gel electrophoresis (DGGE). We determined phylogenetic assemblages, including Actinobacteria, Bacteroidetes, Cyanobacteria, Alpha- and Gammaproteobacteria, and Marine Group II Euryarchaea, and successfully revealed their spatial distribution patterns. At most stations, Bacteria had higher diversity than Archaea, indicated by the relatively higher Shannon-Weaver indexes and numbers of operational taxonomic units (OTUs). Canonical correspondence analysis (CCA) and redundancy analysis (RDA) demonstrated that the community compositions of bacterial populations in the Sea of Okhotsk were closely associated with total prokaryote abundance, while the spatial distributions of bacterial phylogenetic groups were more related to both the concentration of dissolved organic nitrogen (DON) and the ratio of DON versus dissolved organic carbon concentration (DOC:DON). On the other hand, the spatial variation of the community composition of Archaea had no significant association with environmental parameters.
\end{abstract}

KEY WORDS: Phylogenetic diversity $\cdot$ Bacteria $\cdot$ Archaea $\cdot$ Okhotsk Sea $\cdot$ Canonical correspondence analysis $\cdot \mathrm{CCA} \cdot$ Redundancy analysis $\cdot$ RDA

\section{INTRODUCTION}

Bacteria and Archaea play crucial roles in biogeochemical cycles of carbon and other elements in the ocean (Azam 1998, DeLong 2003). A large fraction of primary production becomes dissolved organic matter (DOM) (Williams 1981) by various mechanisms in the food web, and this part of the primary production is almost exclusively accessible to heterotrophic Bacteria and Archaea (Azam et al. 1983, Azam 1998, Fuhrman et al. 2006). As a result, the uptake of organic matter by heterotrophic prokaryotes is a major carbon-flow pathway, and its variability can change the overall patterns of carbon flux (Williams 1981, Azam 1998).

Research in the past $30 \mathrm{yr}$ has revealed that Bacteria dominate abundance, diversity, and metabolic activity in the ocean (Pomeroy et al. 2007). A major break- through in the assessment of marine microbial diversity came with the application of the molecular phylogeny of the 16S rRNA gene (Giovannoni \& Rappe 2000). Afterwards, unexpectedly high diversity and dynamics of bacterial community structures have been found in different oceanic regions, such as the Arabian Sea (Riemann et al. 1999), the Baltic Sea (Sipura et al. 2005), the North Sea (Herfort et al. 2007), the NW Mediterranean Sea (Schauer et al. 2000, RodriguezBlanco et al. 2009), and the Western North Pacific Ocean (Kataoka et al. 2009a). In addition, Archaea have now been recognized as ubiquitous across the oceans (DeLong 2003), and are generally more abundant in deep waters (Massana et al. 1997, Murray et al. 1998, Teira et al. 2004). Despite limited reports on the genetic diversity of the free-living assemblages in disparate oceanic environments (Massana et al. 2000), 
considerable functional and biogeochemical diversity within the chemoautotrophic (Wuchter et al. 2003) and heterotrophic (Ouverney \& Fuhrman 2000, Teira et al. 2004) planktonic marine Archaea have been revealed.

Although there is a growing number of studies investigating microbial diversity and composition in various oceanic regions, the understanding of biotic and abiotic factors that drive the composition and distribution patterns of the microbial communities is still scarce. Strong relationships between the variability of prokaryotic community composition and population shifts in microzooplankton and among viruses have been demonstrated in previous studies (Winter et al. 2004, Jing et al. 2009), while associations between microbial community structure and environmental factors have been explored under various oceanic conditions (Herfort et al. 2007, Ghiglione et al. 2008). Little horizontal variation in bacterioplankton community was found among stations just a few kilometers apart (near the Anvers Island in the Antarctic; Murray et al. 1998) and $1500 \mathrm{~km}$ apart (in the Arabian Sea; Riemann et al. 1999), whereas significant variation was observed along the coast of the NW Mediterranean Sea (Schauer et al. 2000).

The Sea of Okhotsk is one of the marginal seas of the North Pacific Ocean. Although the Sea is geographically located at a temperate latitude, it has many characteristics of a polar ocean, namely, large seasonal variation in water temperatures $\left(\sim 14^{\circ} \mathrm{C}\right)$ and large amounts of sea ice along the Siberian coast over the northwestern continental shelf of the east coast of Sakhalin Island every winter (Alfultis \& Martin 1987). The Sea of Ohkotsk is recognized as the most productive marine basin amongst the world's oceans (Sorokin \& Sorokin 1999). Nakatsuka et al. (2004) reported that the Amur River water contains approximately $690 \mu \mathrm{M}$ of dissolved organic carbon (DOC), and the input of DOC from the Amur River to the Sea of Okhotsk is esti-

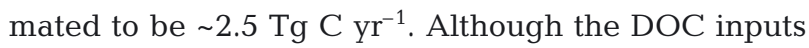
from the Amur River may affect the community composition of Bacteria and Archaea in the Sea of Okhotsk, no study on this has been done yet. In the present paper, we report the spatial distribution of bacterial and archaeal assemblages in the surface water of the Sea of Okhotsk in the context of environmental factors.

\section{MATERIALS AND METHODS}

Sample collection. Surface seawater samples (2 to $4 \mathrm{~m}$ ) were collected at 11 stations representing different oceanographic settings in the Sea of Okhotsk and the western subarctic Pacific during August and September 2006, on board the RV 'Professor Khromov' (Fig. 1). Between 0.75 and $1.8 \mathrm{l}$ of seawater were filtered on board; first through a $3 \mu \mathrm{m}$ and then a $0.22 \mu \mathrm{m}$ pore-size membrane ( $47 \mathrm{~mm}$ diameter, Millipore). The membranes were frozen and stored at $-80^{\circ} \mathrm{C}$ until DNA extraction was done on land.

Water temperature and salinity were measured by a Sea-Bird Electronics CTD system (SBE 911 plus). Chlorophyll (chl) $a$ and macro-nutrient concentrations were determined by a Turner Designs 10-AU fluorometer and a Bran+Luebbe QuAAtro autoanalyzer, respectively (Liu et al. 2009).

Flow cytometry. Water samples $(1 \mathrm{ml})$ were also taken for flow-cytometric determination of the abundance of prokaryotic cells, which included heterotrophic Bacteria, Archaea, and autotrophic picocyanobacteria. Seawater samples were fixed with $0.2 \%$ (final concentration) paraformaldehyde and stored at $-80^{\circ} \mathrm{C}$ until analysis. For counting autotrophic and heterotrophic prokaryotes, a FACSCalibur flow cytometer equipped with a $15 \mathrm{~mW} 488 \mathrm{~nm}$ laser with the standard filter setup was used. Forward and right-angle light scatters and green (515 to $545 \mathrm{~nm}$ ), orange (564 to $606 \mathrm{~nm})$, and red $(>650 \mathrm{~nm})$ fluorescence were recorded, the data saved and analyzed using CYTOWIN software (Vaulot 1989). Autotrophic picocyanobacteria Synechococcus spp. were distinguished from picoeukaryotes primarily by strong orange autofluorescence from phycoerythrin (Liu et al. 2009). SYBR Green I was added to the samples to a final concentration of $10^{-4}$ of the original stock (Molecular Probes), for enumeration of heterotrophic prokaryotes (Marie et al. 1997).

DOC and dissolved organic nitrogen (DON). Surface seawater for DOC and DON analyses was taken with a plastic bottle with spigot and filtered with a pre-combusted Whatman GF/F filter by connecting the spigot to an inline plastic filter holder. The filtrates were collected into pre-combusted glass vials with Teflon-lined caps and stored frozen. DOC and total dissolved nitrogen (TDN) were simultaneously measured using a Shimadzu TOC-V equipped with a TNM-1 total nitrogen detector. We modified the catalyst packing of TOC-V and changed the flow rate of the compressed air introduced to the $\mathrm{O}_{3}$ generator of the TNM-1 to improve the conversion efficiency of nitrogen compounds to excited nitrite. With these modifications, TDN in reference seawater increased by $19 \%$ and reached a reasonable value (see below). The detailed analytical procedures are given elsewhere (R. Sohrin et al. unpubl.). Dissolved inorganic nitrogen (DIN; the sum of nitrate, nitrite, and ammonium) were measured in an aliquot from the same vial used for DOC and TDN analyses, using TRAACS 2000 (Bran+Luebbe), and DON was calculated by subtracting DIN from TDN. The precision of the quadruplicate analyses of DOC and TDN was $1.5 \%$ and $2.8 \%$ in coefficient of variation $(\mathrm{CV})$, respectively, and the precision of both DON and the DOC:DON ra- 


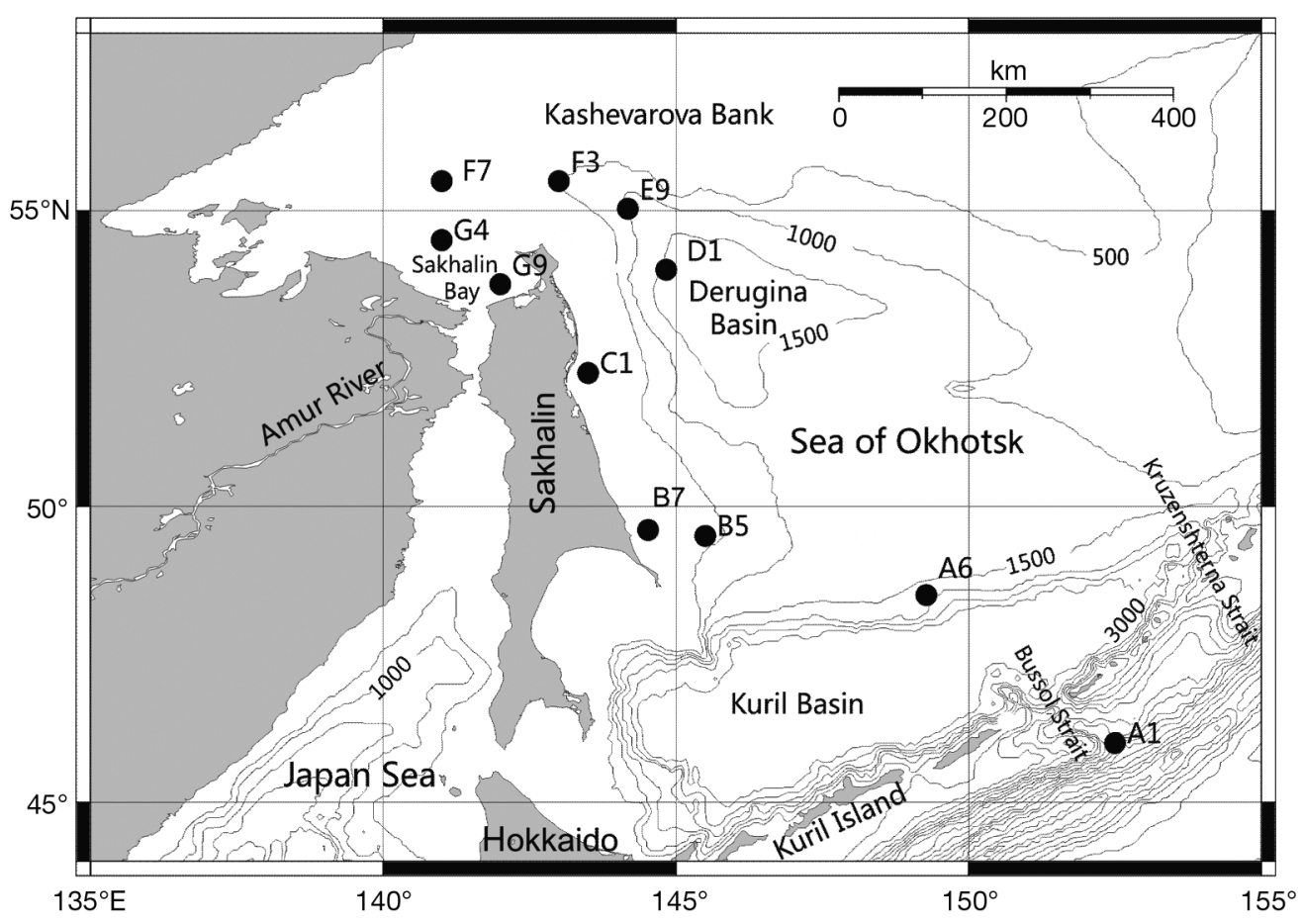

Fig. 1. Location of sampling sites in the Sea of Okhotsk. Stn A1 was on the western edge of the Western Subarctic Gyre (water depth $>4000 \mathrm{~m}$ ); Stn A6 was on the north edge of the deep Kuril Basin; Stns B5 and B7 were on the southern end of the continental shelf east of Sakhalin Island; Stn C1 was a nearshore station east of Sakhalin Island; Stns D1 and E9 were in the Derugina Basin; Stns G4, F3, and F7 were located further north of Sakhalin Bay; and Stn G9 was in the shallow waters of Sakhalin Bay

tio, calculated from the precisions of DOC and TDN, was $12 \%$ in CV. We checked the accuracy and the consistency of our DOC and TDN measurements using the analyses of the reference seawater (DSR; distributed by D. Hansell's laboratory, University of Miami). The amounts of DOC $\left(42.3 \pm 0.7 \mu \mathrm{mol} \mathrm{C} \mathrm{^{-1 }}\right)$ and TDN $(33.1 \pm$ $0.7 \mu \mathrm{mol} \mathrm{N}{ }^{-1}$ ) that we measured were quite constant and matched well with the published DOC (41 to

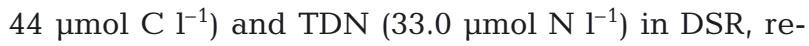
spectively (www.rsmas.miami.edu/groups/biogeochem/ Table1.htm).

DNA isolation and amplification. Total genomic DNA was recovered from biomass collected on the $0.22 \mu \mathrm{m}$ filters, by phenol:chloroform extraction at $60^{\circ} \mathrm{C}$ after lysis with CTAB buffer containing RNase A and Lyzome. Extracted DNA was stored at $-80^{\circ} \mathrm{C}$ after precipitation with isopropanol and then amplified with primer sets specific to 16S rRNA genes of either Bacteria, i.e. 341F (5'-CCT ACG GGA GGC AGC AG$3^{\prime}$ ) and 926R (5'-CCG TCA ATT CMT TTR AGT TT-3') (Muyzer et al. 1996) or Archaea, i.e. 344F (5'-CGG GGY GCA GCA GGC GCG A-3') (Raskin et al. 1994) and 915R (5'-GTG CTC CCC CGC CAA TTC CT-3') (Stahl \& Amann 1991). A (GC) 40 clamp was attached to the $5^{\prime}$ end of the forward primer: 5'-(CGC CCG CCG CGC CCC GCG CCC GTC CCG CCG CCC CCG CCC G-3'). PCR was carried out with $50 \mu \mathrm{l}$ of a master mix that included $5 \mu \mathrm{l}$ of $10 \times$ Buffer, $2 \mu \mathrm{l}$ of $\mathrm{MgCl}_{2}(25 \mathrm{mM})$, $4 \mu \mathrm{l}$ of dNTPs $(2.5 \mathrm{mM}), 0.2 \mu \mathrm{l}$ of Taq polymerase (5 U), and $1 \mu \mathrm{l}$ of each primer $(10 \mu \mathrm{M})$ with the following program: $95^{\circ} \mathrm{C}$ for $3 \mathrm{~min} ; 30$ cycles of $95^{\circ} \mathrm{C}$ for $1 \mathrm{~min}, 55^{\circ} \mathrm{C}$ for $50 \mathrm{~s}, 72^{\circ} \mathrm{C}$ for $1 \mathrm{~min}$; and a final extension at $72^{\circ} \mathrm{C}$ for $10 \mathrm{~min}$. PCR products were stained with ethidium bromide and visualized on a $1 \%$ agarose gel with a UV illuminator.

Denaturing gradient gel electrophoresis (DGGE) and sequencing. GC-PCR products were loaded into a $7 \%$ polyacrylamide DGGE gel, containing a linear denaturant gradient of 30 to $85 \%$. Electrophoresis was conducted using the Bio-Rad DGGE system in $1 \times$ TAE buffer (pH 8) at $60^{\circ} \mathrm{C}$ and $100 \mathrm{~V}$ for $15 \mathrm{~h}$. After completion, the gels were stained with SYBR Green I (10 000 × dilution, Invitrogen) and photographed with the FluorS MultiImager (Bio-Rad). Selected DGGE bands were excised with a sterile stainless blade and soaked overnight in TE buffer ( $\mathrm{pH} 8)$ at $4^{\circ} \mathrm{C}$ before being reamplified with the non-GC primer set. The amplicons were purified with the PureLink ${ }^{\mathrm{TM}}$ Quick Gel Extraction Kit (Invitrogen) prior to automatic sequencing with the BigDye Terminator Cycle Sequencing kit v. 3.1 (Applied Biosystems).

Statistic and phylogenetic analysis. DGGE profiles of both Bacteria and Archaea were analyzed with the GelCompar II software (Applied Maths) after being 
normalized against the $1 \mathrm{~kb}$ Plus DNA Ladder marker (Invitrogen) loaded and migrated along with samples in the gel. DGGE images were converted to densitometric profiles and the number of operational taxonomic units (OTUs) was calculated based on the number of DGGE band positions in each sample. The relative abundance of each phylotype (band position) was estimated based on the ratio of the specific peak height to the height of the total bands in the profile. Furthermore, the Shannon-Weaver diversity index $\left(H^{\prime}\right)$ of each sample was also calculated according to the equation $H^{\prime}=-\Sigma\left(P_{i} \times \log P_{i}\right)$, where $P_{i}=n_{i} / N$, and in turn where $n_{i}$ is the height of a peak and $N$ is the sum of all the peak heights in the densitometric profile.

In order to reveal patterns among stations regarding the distribution of bacterial and archaeal assemblages, detrended correspondence analysis (DCA) was carried out using CANOCO V4.5 (BiometricsPlant Research International) to determine whether linear or unimodal species models were more suitable for our data. In DCA, the correspondence analysis axes are divided into segments, and the sample scores of the second axis are reassigned to be centered on the centroid to remove distortion. The length of the first DCA axis is $<4$ for bacterial populations and $<1$ for archaeal populations; therefore, canonical correspondence analysis (CCA) and redundancy analysis (RDA), which assume unimodal and linear distributions of OTUs along environmental gradients, respectively, were performed for the respective bacterial and archaeal assemblages in order to reveal the relationships between community structures and environmental variables. In addition, RDA was conducted to search for correlations between bacterial groups and environmental factors. The cumulative intensities of DGGE bands belonging to the same bacterial phylogenetic groups were used as species input. Abiotic and biotic factors (see Table 1) were included as explanatory variables. The effects of high collinearity among those factors was removed by eliminating variables with variance inflation factors $(\mathrm{VIF})>20$, one at a time beginning with the variable with the highest VIF. Forward selection was then used to determine the minimum set of environmental variables that could explain the largest amount of variance in the community. The statistical significance of an explanatory variable added in the course of forward selection was tested with the Monte Carlo permutation test (999 permutations, $\mathrm{p} \leq 0.05$ ). For all community ordination analyses, biplot scaling was used.

All sequences obtained from excised bands were submitted to the online RDP-II CHECK_CHIMERA program to check for sequence integrity and chimeras. For each non-chimera sequence, primer sequences were excluded and the NCBI GenBank
BLAST program (www.ncbi.nlm.nih.gov) was used to determine their approximate phylogenetic affiliations. All sequences were aligned in the Clustal X program and phylogenetic trees were constructed using the DNADIST and NEIGHBOR programs in the PHYLIP package (version 3.68) (Felsenstein 1989). Tree topology is supported by the bootstrap values for 1000 replications.

Nucleotide sequence accession numbers. Partial 16S rRNA gene sequences obtained from the present study were submitted and deposited in GenBank under accession numbers GQ201936 to GQ201997 for Bacteria and GQ201923 to GQ201935 for Archaea.

\section{RESULTS}

\section{Physical, chemical, and biological characteristics of the studied stations}

Environmental variables and biological characteristics for each sampling station are listed in Table 1. Stn A1 was characterized by high nitrate $(7.2 \mu \mathrm{M})$ and low chl a $\left(0.48 \mathrm{mg} \mathrm{m}^{-3}\right)$ concentrations. Stns A6, B5, and $\mathrm{B} 7$ all displayed low nutrient and chl a concentrations in the surface water. Stn $\mathrm{C} 1$ had a water depth of only $25 \mathrm{~m}$, a low water temperature $\left(6.7^{\circ} \mathrm{C}\right)$, and a high chl a concentration $\left(7.35 \mathrm{mg} \mathrm{m}^{-3}\right)$. Stns D1 and E9 both were in the Derugina Basin, but differed in nutrient conditions. Stns G4, F3, and F7 were located further north of Sakhalin Bay and had undetectable $\mathrm{NO}_{3}$ concentrations. Stn G9 in the shallow water of Sakhalin Bay (water depth $<30 \mathrm{~m}$ ) was strongly influenced by the freshwater discharge from Amur River as indicated by low salinity (16.48) and high chl a concentration $\left(17.25 \mathrm{mg} \mathrm{m}^{-3}\right)_{i}$ even so, it was both nitrate- and phosphate-depleted. Total heterotrophic prokaryotes (Bacteria and Archaea) ranged from 0.576 to $2.254 \times$ $10^{6} \mathrm{cells} \mathrm{ml}^{-1}$, with the lowest and highest abundance occurring at Stns A1 and G9, respectively. With the exception of Stn A6, where the maximum Synechococcus spp. abundance of $1.9 \times 10^{5}$ cells ml $^{-1}$ was detected, the abundance of Cyanobacteria was generally 1 or 2 orders of magnitude lower than that of heterotrophic prokaryotes. Consequently, the spatial variation of the abundance of total prokaryotes followed that of the heterotrophic prokaryotes.

DOC and DON concentrations ranged from 59.54 to $413.92 \mu \mathrm{M}$ and 3.10 to $11.15 \mu \mathrm{M}$, respectively. Low DOC and DON concentrations occurred at stations in the North Pacific Ocean (Stn A1) and oligotrophic Kuril Basin (Stn A6). On the other hand, Stn G9 in Sakhalin Bay had the highest DOC and DON concentrations, as well as the highest value for the DOC:DON ratio, which indicated a strong fluvial source for its DOM. 


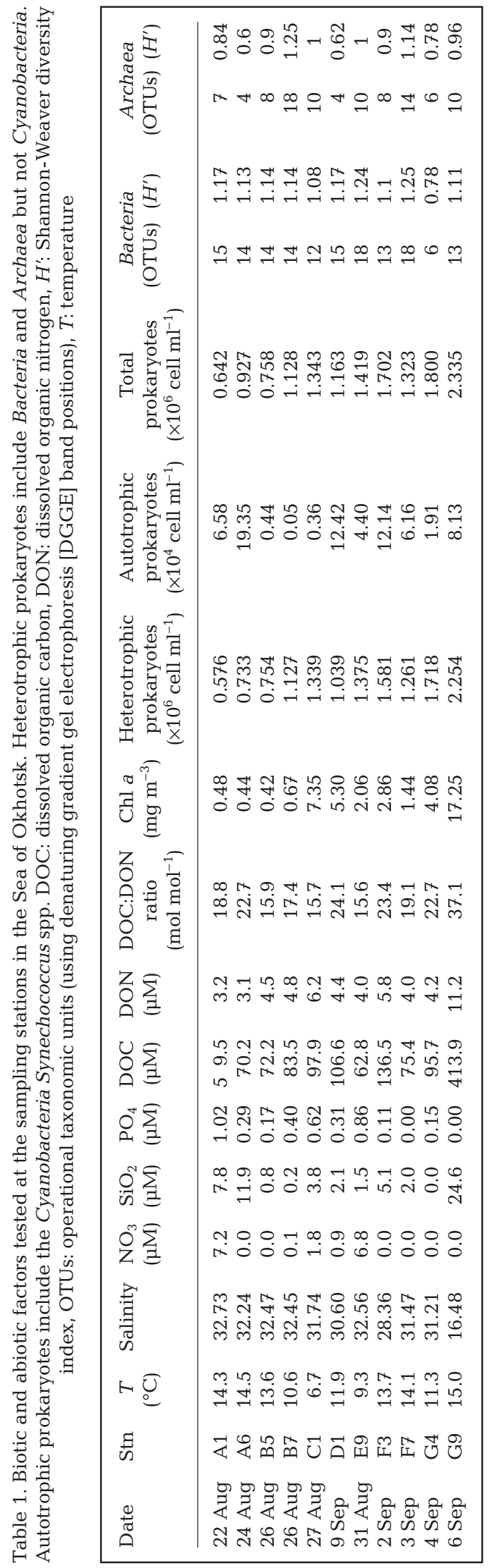

\section{Variations in bacterial and archaeal community composition}

DGGE profiles of bacterial assemblages exhibited a total of 61 OTUs (different band positions). Numbers of OTUs per sample ranged from 6 at Stn G4 to 18 at Stns E9 and F7 (Table 1). Highest and lowest ShannonWeaver indexes for bacterial diversity were obtained at Stn F7 $\left(H^{\prime}=1.25\right)$ and Stn G4 $\left(H^{\prime}=0.78\right)$, respectively. The numbers and positions of bright DGGE bands in each sample varied remarkably, suggesting distinct distributions of dominant bacterial populations.

As to archaeal assemblages, a total of 72 archaeal OTUs were identified. At most stations, archaeal assemblages had relatively lower Shannon-Weaver indexes and numbers of OTUs compared to the corresponding bacterial assemblages. The lowest and highest numbers of OTUs and Shannon-Weaver index for archaeal assemblages occurred at Stn A6 (OTUs $=4$, $\left.H^{\prime}=0.6\right)$ and Stn B7 (OTUs $\left.=18, H^{\prime}=1.25\right)$, respectively.

Ordination analysis of the bacterial community was carried out using all the DGGE bands and the environmental variables listed in Table 1. After excluding factors with $\mathrm{VIF}>20,7$ environmental variables were used for CCA. Forward selection analysis with significance tests of Monte Carlo permutations indicated that prokaryote abundance contributed significantly to the total variance $\left(\lambda_{\mathrm{A}}=0.59 ; \mathrm{p}=0.004\right)$. Close correlations were found between prokaryote abundance and the first axis $(r=0.915)$, between temperature and the second axis $(\mathrm{r}=0.763)$, and between DON and chl a $(\mathrm{r}=$ 0.931). The sum of all eigenvalues indicated an overall variance of 3.501 in the data set and the total variance that could be explained by environmental variation accounted for 2.691, as indicated by the sum of all canonical eigenvalues. Regarding the variance of OTU data (DGGE bands), the first axis explained $18.1 \%$ of the total variation, the first and the second axes explained $32.7 \%$, and all 4 axes together explained $56.7 \%$. Species-environment correlations factors were almost 1 for all 4 axes, indicating a significant relationship between species and environmental variables.

Biplot scaling of CCA based on the canonical axes 1 and 2 demonstrated the inter-sample relationship (Fig. 2). Prokaryote abundance explained most of the variation in the phylogenetic composition of Bacteria; temperature explained most of the variation of the second axis. Clear distribution patterns of the bacterial community were shown in the plot: Stn G9, affected by discharge from the Amur River, had high prokaryote abundance, chl a and DOM concentrations, and DOC:DON ratio, but was depleted of inorganic nutrients (nitrate and phosphate), and therefore was plotted 


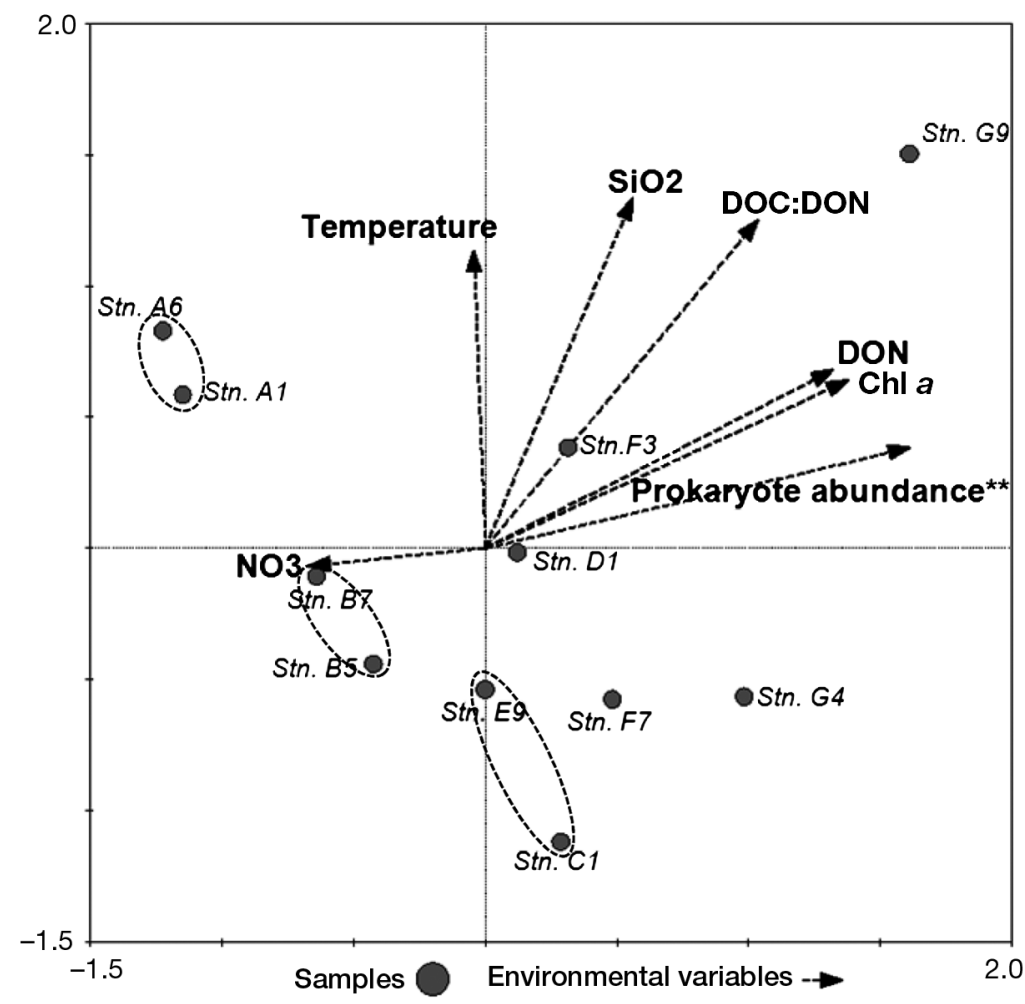

Fig. 2. Canonical correspondence analysis (CCA) biplot based on DNA banding patterns from denaturing gradient gel electrophoresis (DGGE) of bacterial communities sampled at different stations with the abiotic data set as explanatory variables. ${ }^{* *}$ Significant at $\mathrm{p} \leq 0.01$ as determined by 999 Monte Carlo permutations. DOC $(\mathrm{N})$ : dissolved organic carbon (nitrogen)

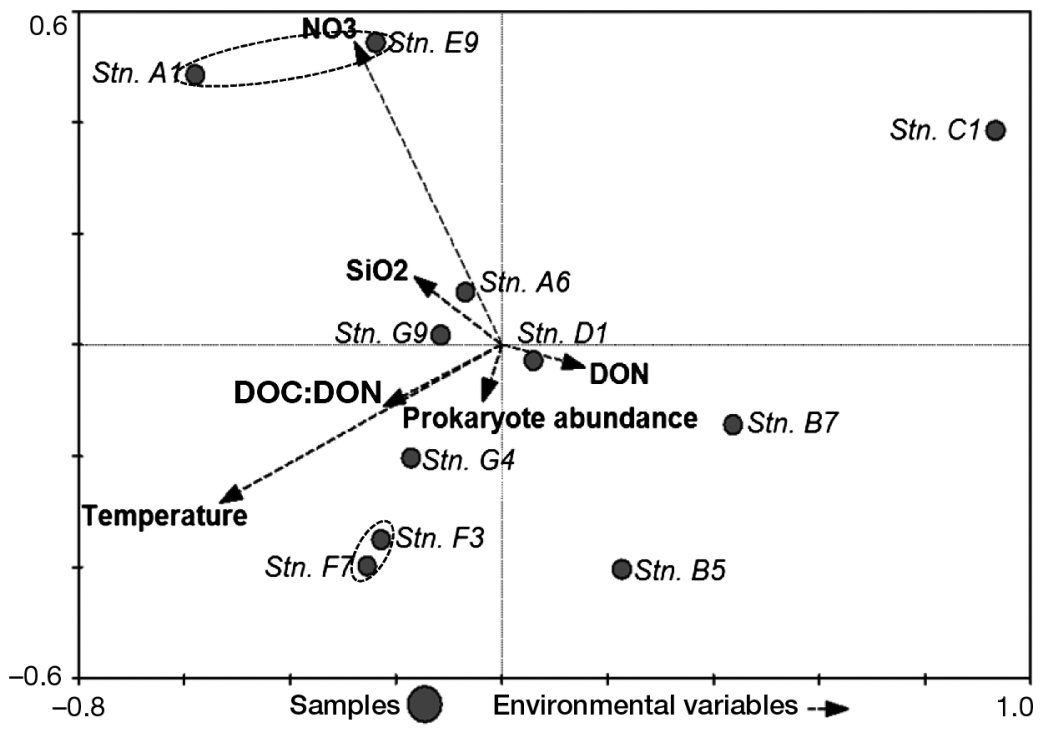

Fig. 3. Redundancy analysis (RDA) biplot based on DNA banding patterns from denaturing gradient gel electrophoresis (DGGE) of archeal communities sampled at different stations with the abiotic data set as explanatory variables. DOC $(\mathrm{N})$ : dissolved organic carbon (nitrogen) distantly from the other stations. Closely related stations grouped together in pairs included Stns A1 and A6 with very low DOM, Stns B5 and B7 with a low DOC: DON ratio, and Stns $\mathrm{C} 1$ and E9 with low temperature. Stns A1, A6, B5, and B7 had low chl a concentrations and prokaryote abundance; thus, all of these stations were plotted opposite to these parameters.

After removing factors with VIF $>20$, six environmental variables were included in the RDA of the archaeal community. The selected environmental variables explained $56.4 \%$ of the total variation in the archaeal community structure, with the 2 main axes explaining $26.1 \%$. Temperature $\left(\lambda_{\mathrm{A}}=0.12\right)$ and $\mathrm{NO}_{3}$ concentration $\left(\lambda_{\mathrm{A}}=0.11\right)$ explained more of the total variance than other environmental factors and were closely associated with the first ( $\mathrm{r}=$ $0.663)$ and second $(r=0.810)$ axes, respectively. Biplot scaling focused on the intersample relationship (Fig. 3) and demonstrated that Stn C1 with the lowest temperature and DOC:DON ratio was plotted distantly from other stations. Stns A1 and E9 with very high $\mathrm{NO}_{3}$ concentration were plotted closely to the $\mathrm{NO}_{3}$ arrow. Stns F3 and F7 with high temperature and DOC:DON ratio were also grouped closely together.

\section{Phylogenetic analysis and community structure}

All visualized bands were excised using a clean razor blade. In total, 67 bands were excised from the bacterial DGGE gels and 62 were successfully sequenced; BLAST search indicated that all of them belonged to bacterial domains, with similarities ranged from 85 to $99 \%$.

Neighbor-joining trees were constructed to reveal the detailed relationship of our sequences with other known sequences from the GenBank database. All bacterial 16S rDNA sequences belonged to the bacterial groups of Actinobacteria, Bacteroidetes, Cyanobacteria, Gammaproteobacteria or Alphaproteobacteria (Fig. 4). Among our bacterial sequences, 22 sequences fell into the clade of marine Cyanobacteria, especially Synechococcus spp.; 7 sequences belonged to the clade of 
Aquifex pyrophilus (M83548)

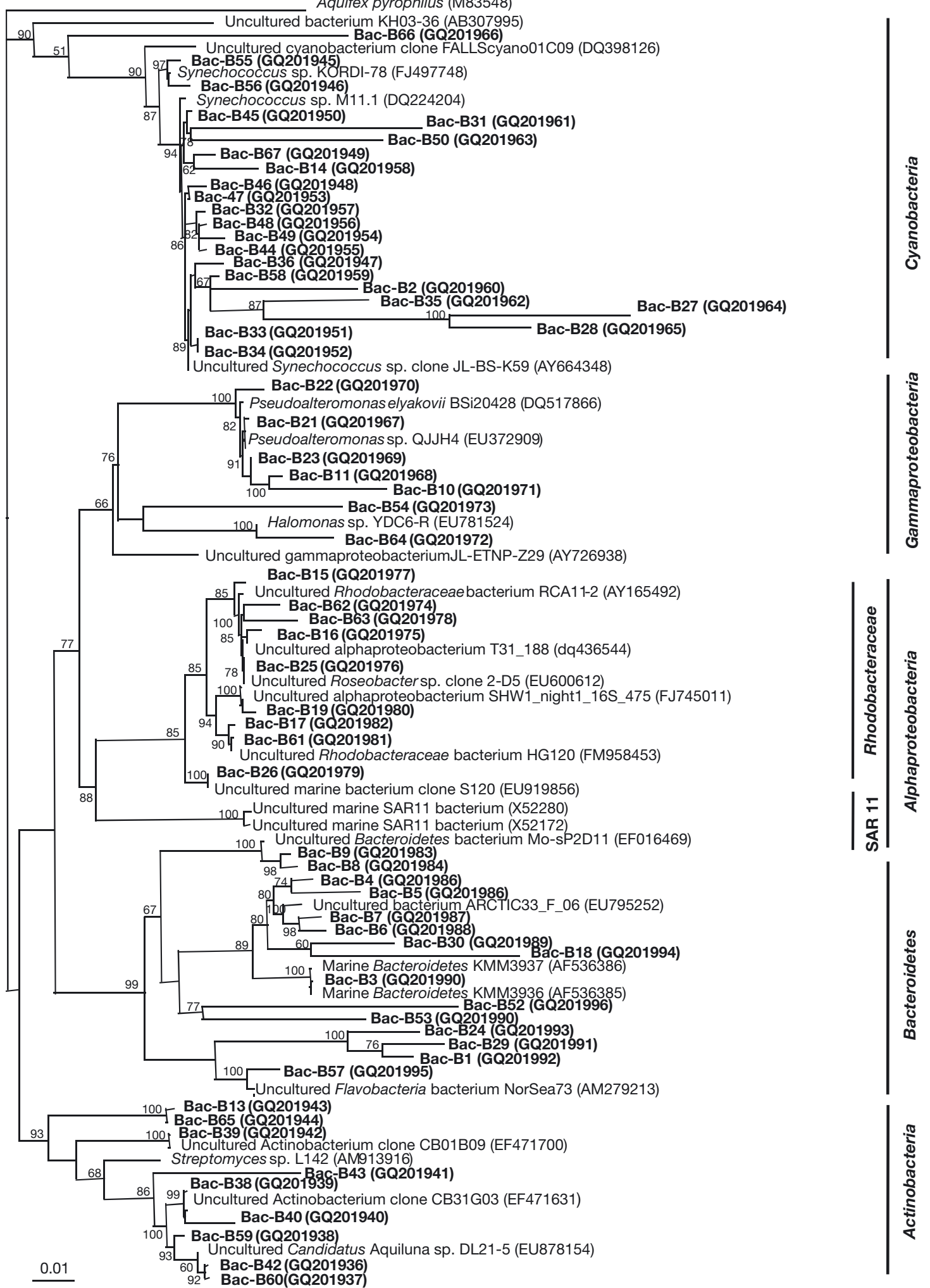

Fig. 4. Neighbor-joining tree showing inferred phylogenetic relationships of the bacterial 16S rRNA gene sequences (Escherichia coli positions 358 to 906) obtained from the 11 stations in the Sea of Okhotsk. Aquifex pyrophilus was used as outgroup. Scale bars indicate Jukes-Cantor evolutionary distances and correspond to $1 \%$ difference in nucleotide sequence. Bootstrap values of $>50$ (for 1000 iterations) are indicated at the nodes. Sequences obtained as part of the present study are in bold, and GenBank accession numbers are given in parentheses 
Gammaproteobacteria, 9 to the clade of Alphaproteobacteria; the clade of Bacteroidetes included 15 of our sequences and 4 of them were related to uncultured Flavobacteria; 9 sequences fell into the clade of Actinobacteria.

On the other hand, a total of 39 bands were excised from the archaeal DGGE gels, but 26 of the sequences did not have close relatives in the domain of Archaea, and therefore only 13 archaeal sequences were used in the subsequent phylogenetic analysis. All the archaeal 16S rDNA sequences obtained from the present study affiliated with the group Euryarchaeota, and more specifically with Marine Group II Euryarchaea (Fig. 5).

Distinct bacterial groups dominated at each station (Fig. 6A): highest relative abundances (in \%) of Actinobacteria and Bacteroidetes were found at Stns C1 and F7, respectively; Cyanobacteria were the predominant group at most stations, with the highest percentage found at Stn G9; Gammaproteobacteria were only recovered at coastal Stns C1, E9, F7, and G9, and accounted for higher percentages at Stn E9 only; Alphaproteobacteria, including Rhodobacteraceae, occurred in relatively higher proportions at Stn G4; and both Gammaproteobacteria and Alphaproteobacteria (non-Rhodobacteraceae) were absent from Stns D1 and F3. Furthermore, RDA biplot illustrated the relationship between bacterial phylogenetic groups and associated environmental factors. The first and second axes contributed 39.5 and $17.3 \%$, respectively, to the overall pattern (Fig. 6B). The first axis was associated with the DOC:DON ratio, while the second axis was mainly represented by the concentration of DON. DON explained relatively more of the total variance than the other environmental factors analyzed $\left(\lambda_{A}=\right.$ $0.21 ; \mathrm{p}=0.05)$. The biplot showed Gammaproteobacteria on the left side in Fig. 6B, in the opposite direction of the DOC:DON ratio, which was consistent with their highest relative abundance being found at Stn E9, where the DOC:DON ratio was the lowest among all studied stations. Actinobacteria were distributed distantly from other bacterial phylogenetic groups and in the direction of DON but opposite to temperature, which is in agreement with their high relative abundance being found at Stn C1, with relatively high DON but lowest temperature.

\section{DISCUSSION}

Although DGGE is very useful for screening the variabilities of complex microbial community structures on spatial and temporal scales, it should be noted that the band intensity does not necessarily represent the abundance of each phylotype. Previous studies reported that different regions of the 16S rRNA gene un- der different DGGE conditions might result in different resolutions of separation; only relatively short sequences ( 500 bp) were suitable for separation; DNA fragments with a certain amount of sequencing variations may not always possible to be separated (Myers et al. 1985, Vallaeys et al. 1997). In addition, DGGE profiles can only reveal populations whose biomass accounts for $>1 \%$ of the environmental samples (Muyzer et al. 1993). Because of the intrinsic limitations of DGGE as mentioned above, plus the possibility of bias introduced during DNA extraction and PCR, DGGE profiles could not be used for the absolute quantitative estimation of a specific phylogenetic group. Consequently, relative abundance is used throughout the text to refer to the proportions of DNA from each phylogenetic group to the total DNA amplified.

\section{Phylogenetic composition of Bacteria and Archaea}

Like in other marine environments, bacterial assemblages in the Sea of Okhotsk were composed mainly of Proteobacteria, Bacteroidetes, and Cyanobacteria (Giovannoni \& Rappe 2000, Rodriguez-Blanco et al. 2009). Cyanobacteria of the genus Synechococcus are major components of the marine picophytoplankton in the global oceans, and it is not surprising that about one-third of our bacterial sequences belonged to the clade of Cyanobacteria and were closely related to Synechococcus. Phylogenetic diversity of Synechococcus had been previously reported from the Sea of Okhotsk based on discrepancies of the internal transcribed spacer (Jing et al. 2009), which showed that Stn G9 was composed exclusively of subcluster 5.2 Synechococcus, while the other stations were dominated by subcluster 5.1 Synechococcus, especially Clades I and IV. Similarly, using the 16S rRNA gene, the results of the present study demonstrate that both marine subcluster 5.1 (Clade I) and 5.2 Synechococcus occurred in the Sea of Okhotsk, and the latter were exclusively detected at Stn G9 in Sakhalin Bay, which receives a large amount of freshwater discharge from the Amur River (Ogi et al. 2001). The rest of the stations were dominated by subcluster 5.1 Synechococcus, with most of the sequences belonging to Clade I Synechococcus, which is consistent with the conclusion that Clade I Synechococcus were the dominant clade in high-latitude coastal and continental shelf zones (Zwirglmaier et al. 2008).

Alphaproteobacteria and Gammaproteobacteria generally dominate in open-ocean environments (Giovannoni \& Stingl 2005) and a recent study also showed that Gammaproteobacteria are predominant in the western North Pacific Ocean where subarctic Oyashio waters encounter subtropical Kuroshio waters (Ka- 

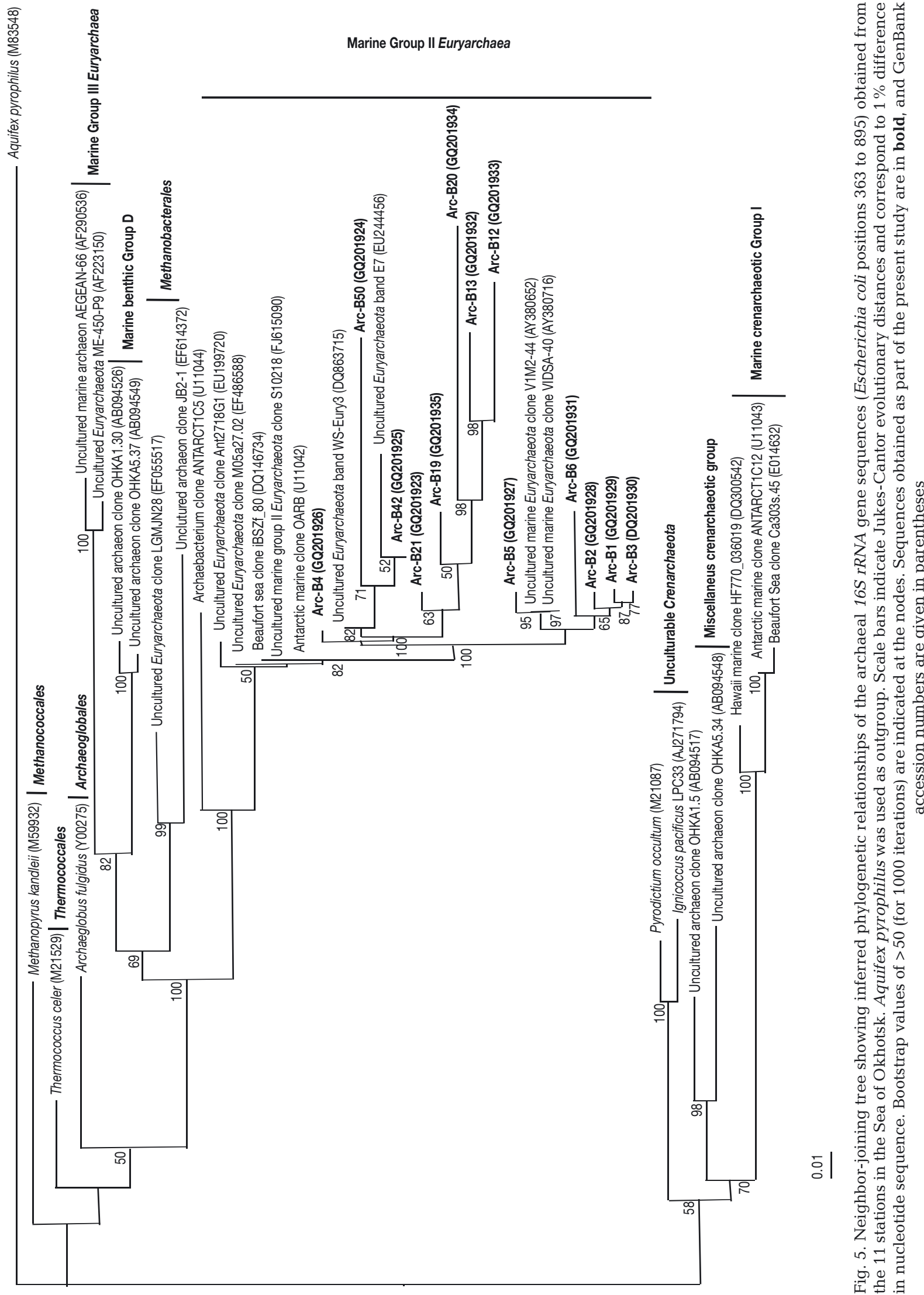

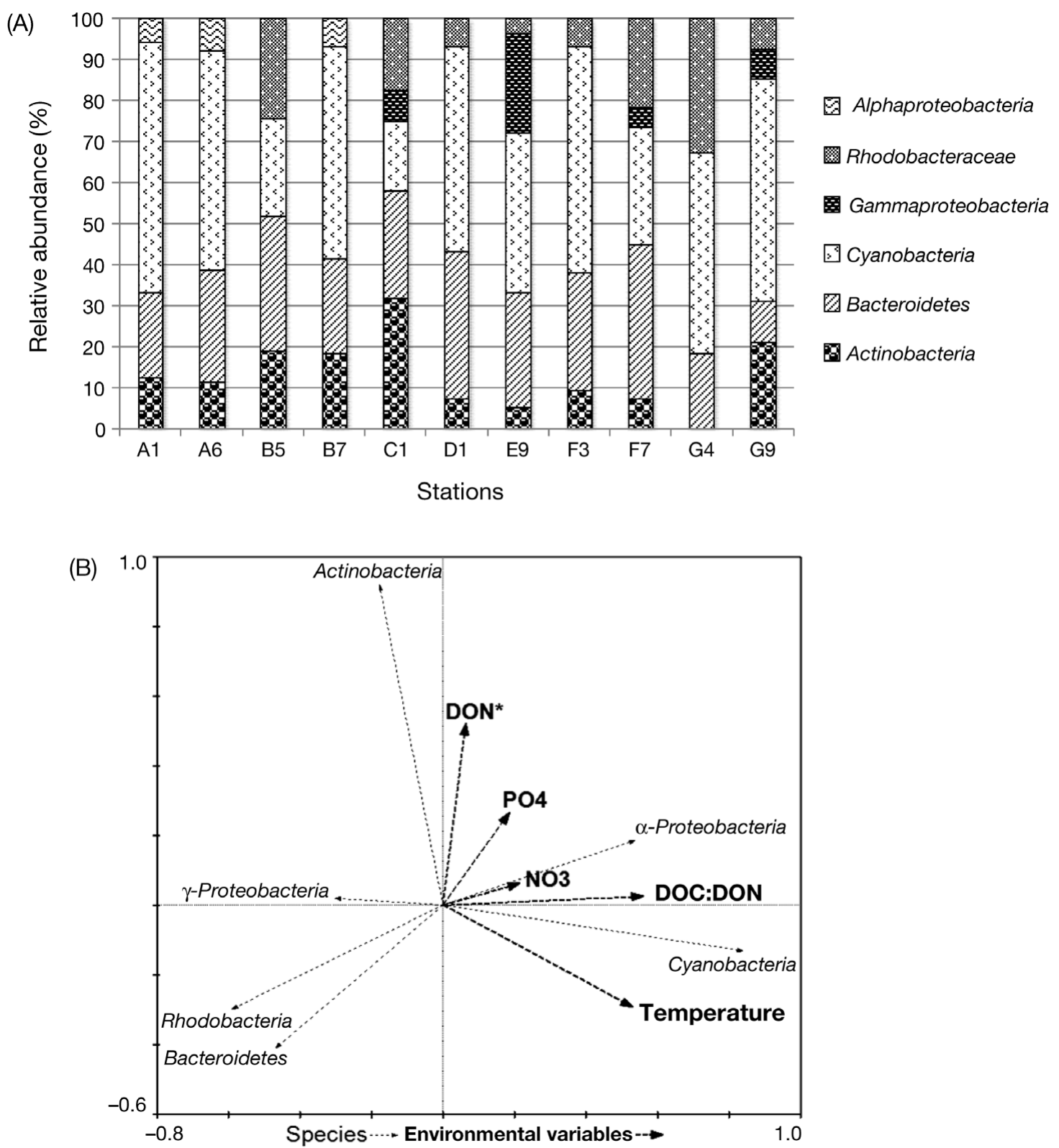

Fig. 6. (A) Frequency of the most common 16S rRNA gene clusters of Bacteria in the surface water of each station in the Sea of Okhotsk. (B) Redundancy analysis (RDA) biplot based on phylogenetic groups of bacterial populations recovered from different stations with the abiotic data set as explanatory variables. ${ }^{*}$ Significant at $p \leq 0.05$ as determined by 999 Monte Carlo permutations. DOC $(\mathrm{N})$ : dissolved organic carbon (nitrogen)

taoka et al. 2009a). A total of 6 sequences of the clade of Gammaproteobacteria were closely clustered with Pseudoalteromonas and 2 others were grouped with Halomonas sp. YDC6-R (EU781524) isolated from deep-sea hydrothermal vent sediment in the Indian Ocean. As Gammaproteobacteria mainly occurred in shallow coastal stations in the present study (Fig. 6A), it is possible that they were brought to the water column from reduced sediments. In the clade of Alphaproteobacteria, all 9 sequences clustered with marine Rhodobacteraceae bacteria and none of them related to SAR11, which is considered to be the most abundant phylogenetic group in the sea (Morris et al. 2002) and has been detected in the western North Pacific Ocean (Kataoka et al. 2009b). The reason that sequences belonging to the SAR11 group were not detected in the present study is very likely due to methodological limitation (Sánchez et al. 2009). The SAR11 group is known to have a high degree of microdiversity (Acinas et al. 2004), which may lead to the 
presence of faint DGGE bands that are hard to identify, retrieve and sequence.

Bacteroidetes have a ubiquitous distribution in various marine systems and are identified as the predominant bacterioplankton group in some oceanic waters, as revealed by fluorescence in situ hybridization (FISH) (Kirchman 2002). Although Bacteroidetes were not detected in the Oyashio, Kuroshio, and OyashioKuroshio transition regions of the western North Pacific Ocean (Kataoka et al. 2009a), they were often observed in the Western Subarctic Gyre during an in situ iron fertilization experiment in summer (Kataoka et al. 2009b). From the Bacteroidetes sequences we found, 11 sequences were grouped with uncultured Bacteroidetes clones obtained in Monterey Bay, Arctic Ocean, or with marine Bacteroidetes isolates (Nedashkovskaya et al. 2003); 4 other sequences were related to uncultured Flavobacteria clones obtained from the North Sea (Alonso et al. 2007).

Actinobacteria are widely dispersed through the marine environments with high diversity and they have been detected as a minor fraction $(3.6 \%)$ of the bacterial isolates from coastal sediments in the Sea of Okhotsk (Jardillier et al. 2005). In the clade of Actinobacteria, all 9 sequences exhibited a closer relationship with uncultured actinobacterium clones from the surface water of Chesapeake Bay (Kan et al. 2008) and Streptomyces sp. L142 from the Baltic Sea (Wiese et al. 2009) rather than with those recovered from the sediments of the Sea of Okhotsk (Jardillier et al. 2005).

A general, vertical distribution trend in different marine regions demonstrated that Group II Euryarchaea are the dominant archaeal phylotypes in the surface seawater, while Group I Crenarchaea are the dominant phylotypes at depth (Massana et al. 2000). Therefore, it is not unexpected that all the sequences retrieved from the surface water of the Sea of Okhotsk should belong to Marine Group II Euryarchaea, further supporting the dominance of Group II planktonic Euryarchaea in the water layers near the ocean's surface (DeLong 2003). Another reason for the exclusive constitution of Group II Euryarchaea in the Sea of Okhotsk was potentially the cross-amplification of members of the domain Bacteria resulting from the low specificity of primer Arch915, which has been discussed in detail previously (Wells et al. 2006). Similarly, using the same primer and DGGE, Winter et al. (2009) also detected only members of Marine Group II Euryarchaea among the archaeal community in the Mediterranean Sea, for which they suggested that the primer sets had caused a skewed amplification toward Euryarchaea.

Marine Group II Euryarchaea generally have greater phylogenetic diversity than Marine Group I Crenarchaea (Church et al. 2003). In the clade of Group II Euryarchaea, 8 of our sequences were closely related to environmental clones from a temperate North Sea water column (Hoefs et al. 1997), and 5 sequences were grouped together with uncultured marine Euryarchaea clones from tropical marine waters (Kellogg 2004). Although archaeal sequences obtained from seawater in the Arctic (Galand et al. 2006), the Antarctic (DeLong et al. 1994), and the sediment of the Sea of Okhotsk (Jardillier et al. 2005) were included in the phylogenetic tree, they were rather distantly related to our sequences, which implied that archaeal assemblages in the water column of the Sea of Okhotsk are very distinct from those in the polar seas or sediments.

In the present study, Bacteria showed relatively higher diversity at most stations than Archaea as indicated by both the Shannon-Weaver index and numbers of OTUs, which is in agreement with most studies to date (Aller \& Kemp 2008). However, information is lacking on whether the relative proportions and metabolic activities of Bacteria and Archaea within a specific community are related to their diversity. Limited studies suggest that Archaea are physiologically diverse as a whole, and the diversity of bacterial and archaeal communities may be linked to each other and influenced by the same factors (Aller \& Kemp 2008).

\section{Factors associated with bacterial and archaeal community structures}

Environmental parameters were generally considered determining factors for the distribution and abundance of bacterial assemblages (Fuhrman et al. 2008). For example, changes in nutrient loading could cause variations in the biomass and community composition of Bacteria (Sipura et al. 2005), and the distinct seasonal shifts of the prokaryotic community composition at the Bermuda time-series study site were found to be closely related to DOC dynamics (Morris et al. 2005). In a recent study on the bacterial communities in the western North Pacific Ocean, temperature and salinity were found to have high impacts on bacterial assemblages at the Kuroshio stations, while chl $a$ and nitrate concentrations were the determining factors at the Oyashio stations (Kataoka et al. 2009a). In the present study, multivariate analysis was applied for investigating the abiotic and biotic factors that affect community variations. The remarkable disparities in the spatial variation of the bacterial community among stations detected in the present study appeared to be significantly related to prokaryote abundance. Although geographically adjacent stations, such as Stns A1 and A6, and Stns B5 and B7, had less inter-sample distance on the biplot scaling, the spatial variation of bacterial communities at all stations as a whole could not be explained by geographical proximity. 
In addition, organic and inorganic nutrients had been demonstrated to have profound influence on the broad distribution of some major bacterial phylogenetic groups (Giovannoni et al. 1995). Based on the facts that nutrients, particularly nitrate, were depleted at most of our sampling stations, the Sea of Okhotsk was at the post-bloom condition during the present study (Liu et al. 2009). Multivariate analysis in the present study demonstrated that DON concentration and the DOC:DON ratio explained most of the effects of the environmental factors on the spatial distribution of different bacterial phylogenetic groups in the study area (Fig. 6). Based on a study by R. Sohrin et al. (unpubl.) conducted in the surface water across the study area during the same cruise as for the present study, the concentration of DOC (and DON) showed significant positive and negative correlation with chl $a$ and salinity, respectively. Likewise, a negative correlation between salinity and DOC:DON ratio was found, indicating that the quality of DOM changed from the fluvial one (high DOC:DON ratio) to the autochthonous one (low DOC:DON ratio) along the salinity gradient. Those results were consistent with the findings of an earlier study (Nakatsuka et al. 2004). It should be pointed out that some bacterial phylogenetic groups were not properly detected due to methodological limitations. For example, Alphaproteobacteria, including SAR11, are known as the most abundant and ubiquitous bacterial phylogenetic group in the ocean (Morris et al. 2002, Giovannoni \& Stingl 2005), but were not detected at some of our stations. Therefore, methodological differences in addition to geographical and temporal variations should be considered when comparing different studies.

Besides the depth partition of the different archaeal phylotypes, e.g. Group II Euryarchaea dominating in the surface seawater and Group I Crenarchaea dominating in the deep ocean (Massana et al. 2000), no other reports regarding the effects of environmental factors on the spatial distribution of archaeal phylogenetic groups exist. In the present study, the spatial variation in the composition of Archaea in the surface water of the Sea of Okhotsk was mainly influenced by temperature and $\mathrm{NO}_{3}$ concentration, though neither factor was statistically significant. The results suggest that environmental factors other than measured in the present study might also influence archaeal phylogenetic distributions.

\section{CONCLUSIONS}

In conclusion, variations in bacterial and archaeal community structures among stations in the Sea of Okhotsk have been uncovered, which could be ex- plained by the physical, chemical, and biological characteristics of the water column. The phylogenetic compositions of the bacterial assemblages at the 11 stations in the Sea of Okhotsk were mainly associated with total prokaryote abundance, while environmental variables explained very little of the archaeal community composition. In addition, DON concentration and the DOC:DON ratio appeared to be responsible for the spatial distribution of different bacterial taxa.

Acknowledgements. We thank chief scientist, Dr. T. Nakatsuka, captain and crew of RV 'Professor Khromov', and the scientific party on board for their assistance during the cruise. We also thank Dr. C. Chung for DNA extraction and C. Lee for technical assistance. Critical reviews provided by 3 anonymous reviewers improved the quality of the paper. This research is supported by Hong Kong Research Grants Council grants (HKUST6414/06M and 661407) and an Areas of Excellence grant (AoE/P-04/04; to the Centre for marine environmental research and innovative technology [MERIT]) to H.L.

\section{LITERATURE CITED}

Acinas SG, Klepac-Ceraj V, Hunt DE, Pharino C, Ceraj I, Distel DL, Polz MF (2004) Fine-scale phylogenetic architecture of a complex bacterial community. Nature 430: $551-554$

Alfultis MA, Martin S (1987) Satellite passive microwave studies of the Sea of Okhotsk ice cover and its relation to oceanic processes, 1978-1982. J Geophys Res 92: 13013-13028

Aller JY, Kemp PF (2008) Are Archaea inherently less diverse than Bacteria in the same environments? FEMS Microbiol Ecol 65:74-87

Alonso C, Warnecke F, Amann R, Pernthaler J (2007) High local and global diversity of Flavobacteria in marine plankton. Environ Microbiol 9:1253-1266

Azam F (1998) Microbial control of organic carbon flux: the plot thickens. Science 280:694-696

Azam F, Fenchel T, Field JG, Gray JS, Meyer-Reil LA, Thingstad F (1983) The ecological role of water-column microbes in the sea. Mar Ecol Prog Ser 10:257-263

Church MJ, DeLong EF, Ducklow HW, Karner MB, Preston CM, Karl DM (2003) Abundance and distribution of planktonic Archaea and bacteria in the waters west of the Antarctic Peninsula. Limnol Oceanogr 48:1893-1902

DeLong EF (2003) Oceans of Archaea. ASM News 69: 503-511

DeLong EF, Wu KY, Prezelin BB, Jovine RV (1994) High abundance of Archaea in Antarctic marine picoplankton. Nature 371:695-697

Felsenstein J (1989) PHYLIP-phylogeny inference package (version 3.2). Cladistics 5:164-166

Fuhrman JA, Hewson I, Schwalbach MS, Steele JA, Brown MV, Naeem S (2006) Annually reoccurring bacterial communities are predictable from ocean conditions. Proc Natl Acad Sci USA 103:13104-13109

> Fuhrman JA, Steele JA, Hewson I, Schwalbach MS, Brown MV, Green JL, Brown JH (2008) From the cover: a latitudinal diversity gradient in planktonic marine bacteria. Proc Natl Acad Sci USA 105:7774-7778

Galand PE, Lovejoy C, Vincent WF (2006) Remarkably diverse and contrasting archaeal communities in a large 
arctic river and the coastal Arctic Ocean. Aquat Microb Ecol 44:115-126

Ghiglione JF, Palacios C, Marty JC, Mével G and others (2008) Role of environmental factors for the vertical distribution $(0-1000 \mathrm{~m})$ of marine bacterial communities in the NW Mediterranean Sea. Biogeosciences Discuss 5: 2131-2164

Giovannoni SJ, Rappe M (2000) Evolution, diversity and molecular ecology of marine prokaryotes. In: Kirchman DL (ed) Microbial ecology of the oceans. Wiley-Liss, New York, NY, p 47-84

> Giovannoni SJ, Stingl U (2005) Molecular diversity and ecology of microbial plankton. Nature 437:343-348

Giovannoni SF, Mullins TD, Field KG (1995) Microbial diversity in oceanic systems: rRNA approaches to the study of unculturable microbes. In: Joint I (ed) Molecular ecology of aquatic microbes. Springer-Verlag, Berlin, p 217-248

Herfort L, Schouten S, Abbas B, Veldhuis MJ and others (2007) Variations in spatial and temporal distribution of Archaea in the North Sea in relation to environmental variables. FEMS Microbiol Ecol 62:242-257

Hoefs MJL, Schouten S, de Leeuw JW, King LL, Wakeham SG, Sinninghe Damste JS (1997) Ether lipids of planktonic Archaea in the marine water column. Appl Environ Microbiol 63:3090-3095

Jardillier L, Bettarel Y, Richardot M, Bardot C, Amblard C, Sime-Ngando T, Debroas D (2005) Effects of viruses and predators on prokaryotic community composition. Mol Ecol 50:557-569

> Jing H, Liu H, Suzuki K (2009) Phylogenetic diversity of marine Synechococcus in the Sea of Okhotsk. Aquat Microb Ecol 56:55-63

Kan J, Evans SE, Chen F, Suzuki MT (2008) Novel estuarine bacterioplankton in rRNA operon libraries from the Chesapeake Bay. Aquat Microb Ecol 51:55-56

Kataoka T, Hodoki Y, Suzuki K, Saito H, Higashi S (2009a) Tempo-spatial patterns of bacterial community composition in the western North Pacific Ocean. J Mar Syst 77: 197-207

Kataoka T, Suzuki K, Hayakawa M, Kudo I, Higashi S, Tsuda A (2009b) Temporal changes in community composition of heterotrophic bacteria during in situ iron enrichment in the western subarctic (SEEDS-II). Deep-Sea Res II 56: 2779-2787

Kellogg CA (2004) Tropical archaea: diversity associated with the surface microlayer of corals. Mar Ecol Prog Ser 273: 81-88

> Kirchman DL (2002) The ecology of Cytophaga-Flavobacteria in aquatic environments. FEMS Microbiol Ecol 39: 91-100

Liu H, Suzuki K, Nishioka J, Sohrin R, Nakatsuka T (2009) Phytoplankton growth and microzooplankton grazing in the Sea of Okhotsk during late summer of 2006. Deep-Sea Res Part I 56:561-570

- Marie D, Partensky F, Jacquet S, Vaulot D (1997) Enumeration and cell cycle analysis of natural populations of marine picoplankton by flow cytometry using the nucleic acid dye SYBR-Green I. Appl Environ Microbiol 63: 186-193

Massana R, Murray AE, Preston CM, DeLong EF (1997) Vertical distribution and phylogenetic characterization of marine plaktonic archaea in the Santa Barbara Channel. Appl Environ Microbiol 63:50-56

> Massana R, DeLong EF, Pedros-Alio C (2000) A few cosmopolitan phylotypes dominate planktonic archaeal assemblages in widely different oceanic provinces. Appl Environ Microbiol 66:1777-1787
Morris RM, Rappé MS, Connon SA, Vergin KL, Siebold WA, Carlson CA, Giovannoni SJ (2002) SAR11 clade dominates ocean surface bacterioplankton communities. Nature 420: 806-810

> Morris RM, Vergin KL, Cho JC, Rappé MS, Carlson CA, Giovannoni SJ (2005) Temporal and spatial response of bacterioplankton lineages to annual convective overturn at the Bermuda Atlantic Time-series Study site. Limnol Oceanogr 50:1687-1696

Murray AE, Preston CM, Massana R, Taylor LT, Blakis A, Wu K, DeLong EF (1998) Seasonal and spatial variability of bacterial and archaeal assemblages in the coastal waters near Anvers Island, Antarctica. Appl Environ Microbiol 64:2585-2595

Muyzer G, De Waal EC, Uitterlinden AG (1993) Profiling of complex microbial populations by denaturing gradient gel electrophoresis analysis of polymerase chain reactionamplified genes coding for 16S rRNA. Appl Environ Microbiol 59:695-700

Muyzer G, Hottentrager S, Teske A, Wawer C (1996) Denaturing gradient gel electrophoresis of PCR-amplified 16S rDNA. A new molecular approach to analyze the genetic diversity of mixed microbial communities. In: Akkermans ADL, van Elsas JD, de Bruijn FJ (eds) Molecular microbial ecology manual. Kluwer Academic Publishers, Dordrecht, p 1-23

Myers RM, Fisher SG, Lerman LS, Maniatis T (1985) Nearly all single base substitutions in DNA fragments joined to a GC-clamp can be detected by denaturing gradient gel electrophoresis. Nucleic Acid Res 13:3131-3145

Nakatsuka T, Toda M, Kawamura K, Wakatsuchi M (2004) Dissolved and particulate organic carbon in the Sea of Okhotsk: transport from continental shelf to ocean interior. J Geophys Res 109:C09S14 doi:10.1029/2003JC001909

Nedashkovskaya OI, Suzuki M, Vysotskii MV, Mikhailov VV (2003) Reichenbachia agariperforans gen. nov., sp. nov., a novel marine bacterium in the phylum CytophagaFlavobacterium-Bacteroides. Int J Syst Evol Microbiol 53:81-85

Ogi M, Tachibana Y, Nishio F, Danchenkov MA (2001) Does the fresh water supply from the Amur river flowing into the Sea of Okhotsk affect sea ice formation? J Meteorol Soc Jpn 79:123-129

Ouverney CC, Fuhrman JA (2000) Marine planktonic Archaea take up amino acids. Appl Environ Microbiol 66: 4829-4833

Pomeroy LR, Williams PJ, Azam F, Hobbie EA (2007) The microbial loop. Oceanography 20:28-33

Raskin L, Stromley JM, Rittmann BE, Stahl DA (1994) Groupspecific 16S RNA hybridization probes to describe natural communities of methanogens. Appl Environ Microbiol 60:1232-1240

Riemann L, Steward GF, Fandino LB, Campbell L, Landry MR, Azam F (1999) Bacterial community composition during two consecutive NE monsoon periods in the Arabian Sea studied by denaturing gradient gel electrophoresis (DGGE) of rDNA. Deep-Sea Res Part II 46: 1791-1811

Rodriguez-Blanco A, Ghiglione JF, Catala P, Casamayor EO, Lebaron P (2009) Spatial comparison of total vs. active bacterial populations by coupling genetic fingerprinting and clone library analyses in the NW Mediterranean Sea. FEMS Microbiol Ecol 67:30-42

- Sánchez O, Gasol JM, Balagué V, Massana R, Mas J, PedrósAlió C (2009) Influence of primer mismatch and microdiversity on DGGE results: a case study with SAR11. Aquat Microb Ecol 54:211-216 
Schauer M, Massana R, Pedro-Alio C (2000) Spatial differences in bacterioplankton composition along the Catalan coast (NW Mediterranean) assessed by molecular fingerprinting. FEMS Microbiol Ecol 33:51-59

Sipura J, Haukka K, Helminen H, Lagus A, Suomeal J, Sivonen K (2005) Effect of nutrient enrichment on bacterioplankton biomass and community composition in mesocosms in the Archipelago Sea, northern Baltic. J Plankton Res 27:1261-1272

Sorokin YI, Sorokin PY (1999) Production in the Sea of Okhotsk. J Plankton Res 21:201-230

Stahl DA, Amann R (1991) Development and application of nucleic acid probes. In: Stackebrandt E, Goodfellow M (eds) Nucleic acid techniques in bacterial systematics. John Wiley \& Sons, Chichester, p 205-248

Teira E, Reinthaler T, Pernthaler A, Pernthaler J, Herndl GJ (2004) Combined catalyzed reporter deposition-fluorescence in situ hybridization and microautoradiography to detect substrate utilization by Bacteria and Archaea in the deep ocean. Appl Environ Microbiol 70:4411-4414

Vallaeys T, Topp E, Muyzer G, Macheret V, Laguerre G, Soulas G (1997) Evaluation of denaturing gradient gel electrophoresis in the detection of $16 \mathrm{~S}$ rDNA sequence variation in rhizobia and methanotrophs. FEMS Microbiol Ecol 24:279-285

Vaulot D (1989) CYTOPC: processing software for flow cytometric data. Signal and Noise 2:8

Editorial responsibility: Craig Carlson, Santa Barbara, California, USA
Wells LE, Cordray M, Bowerman S, Miller LA, Vincent WF, Deming JW (2006) Archaea in particle-rich waters of the Beaufort shelf and Franklin Bay, Canadian Arctic: clues to an allochthonous origin? Limnol Oceanogr 51:47-59

Wiese J, Thiel V, Nagel K, Staufenberger T, Imhoff JF (2009) Diversity of antibiotic-active bacteria associated with the brown alga Laminaria saccharina from the Baltic Sea. Mar Biotechnol 11:287-300

Williams PJleB (1981) Incorporation of microheterotrophic processes into the classical paradigm of the planktonic food web. Kieler Meeresforsch 15:1-28

Winter C, Smit A, Herndl GJ, Weinbauer MG (2004) Impact of virioplankton on archaeal and bacterial community richness as assessed in seawater batch cultures. Appl Environ Microbiol 70:804-813

Winter C, Kerros ME, Weinbauer MG (2009) Seasonal changes of bacterial and archaeal communities in the dark ocean: evidence from the Mediterranean Sea. Limnol Oceanogr 54:160-170

- Wuchter C, Schouten S, Boschker HT, Sinninghe S, Damste JS (2003) Bicarbonate uptake by marine Crenarchaeota. FEMS Microbiol Lett 219:203-207

> Zwirglmaier K, Jardillier L, Ostrowski M, Mazard S and others (2008) Global phylogeography of marine Synechococcus and Prochlorococcus reveals a distinct partitioning of lineages among oceanic biomes. Environ Microbiol 10: $147-161$

Submitted: December 14, 2009; Accepted: August 16, 2010 Proofs received from author(s): October 21, 2010 